This manuscript is a preprint that has been accepted for publication in GEOLOGY. The final version of this manuscript is available via the 'Peer-reviewed Publication DOI' link on the righthand side of this webpage. Please feel free to contact any of the authors; we welcome feedback. 


\section{Flexural strike-slip basins}

2 Derek Neuharth ${ }^{1,2}$, Sascha Brune ${ }^{1,2}$, Anne Glerum', Chris K. Morley ${ }^{3}$, Xiaoping Yuan,, 3 Jean Braun ${ }^{1,2}$

$4{ }^{1}$ GFZ German Research Centre for Geosciences, Telegrafenberg, 14473 Potsdam, Germany.

$5 \quad{ }^{2}$ Institute of Geosciences, University of Potsdam, Germany.

$6 \quad{ }^{3}$ PTTEP, Enco, Vibhavadi-Rangsit Road, Chatuchak, Bangkok, 10900, Thailand

$7 \quad{ }^{4}$ School of Earth Sciences, China University of Geosciences, Wuhan, China

9 ABSTRACT

11 Strike-slip faults are classically associated with pull-apart basins where continental crust is 12 thinned between two laterally offset fault segments. We propose a subsidence mechanism to 13 explain the formation of a new type of basin where no substantial segment offset or syn-strike-slip 14 thinning is observed. Such "flexural strike-slip basins" form due to a sediment load creating 15 accommodation space by bending the lithosphere. We use a two-way coupling between the 16 geodynamic code ASPECT and surface-processes code FastScape to show that flexural strike-slip 17 basins emerge if sediment is deposited on thin lithosphere close to a strike-slip fault. These 18 conditions were met at the Andaman Basin Central fault (Andaman Sea, Indian Ocean), where 19 seismic reflection data provide evidence of a laterally extensive flexural basin with a depocenter 20 located parallel to the strike-slip fault trace. 


\section{MOTIVATION}

Near plate boundaries, accommodation space for sedimentary basins is created by (1) lithospheric stretching or cooling, which controls rift-basin formation at divergent boundaries, and (2) lithospheric flexure such as in foreland basins in convergent settings and cratonic sag basins in continental interiors (Allen and Allen, 2013). Pull-apart basins at transform plate boundaries are thought to be related to the first process.

Pull-apart basins form between laterally offset strike-slip fault segments (Mann et al., 1983; Gürbüz, 2010). During strike-slip motion, the area between the offset faults is extended and basement subsidence occurs in this area due to crustal thinning (van Wijk et al., 2017). Pull-apart basins lengthen over time and form as long thin basins with a depocenter that is bounded by the strike- or oblique-slip segments (Seeber et al., 2004). While there are many pull-apart basin examples (e.g., the Dead Sea Basin: Garfunkel and Ben-Avraham, 1996; Death Valley Basin: Serpa et al., 1988), there has not been much discussion on other types of strike-slip basins.

Flexural basins form when an overlying load deflects the lithosphere, e.g., during mountain building, where an orogenic load creates accommodation space for sediment infill. However, under conditions without an orogenic load, basement subsidence may be a consequence of lower-crustal flow triggered by enhanced sedimentation in deep basins (Morley and Westaway, 2006; Clift et al., 2015), e.g., the fans of the Red River (Clift and Sun, 2006) and Pearl River (Dong et al., 2020; both examples are located at the northern continental margin of the South China Sea).

We infer that the creation of sedimentation-induced accommodation space requires and is enhanced by (1) an easily deformable tectonic environment, and (2) focused sedimentation. Both can occur in regions of prior tectonic subsidence. Furthermore, because strike-slip faults may represent highly weakened plate boundaries (Zoback et al., 1987; Provost and Houston, 2003) and transform continental margins commonly follow a phase of thinning (Jourdon et al., 2021), we formulate the key hypothesis of this study: regions near strike-slip faults can represent a

52 The positive feedback between focused sedimentation and flexural subsidence leads to the creation 53 of a previously unrecognized type of basin that we term "flexural strike-slip basin". We test our 54 hypothesis by (1) numerical forward modeling of a strike-slip system subjected to asymmetric 
55 sedimentation, and (2) seismic reflection interpretation from the East Andaman Basin (EAB) in

56 the Andaman Sea (Indian Ocean).

\section{A. Region map}

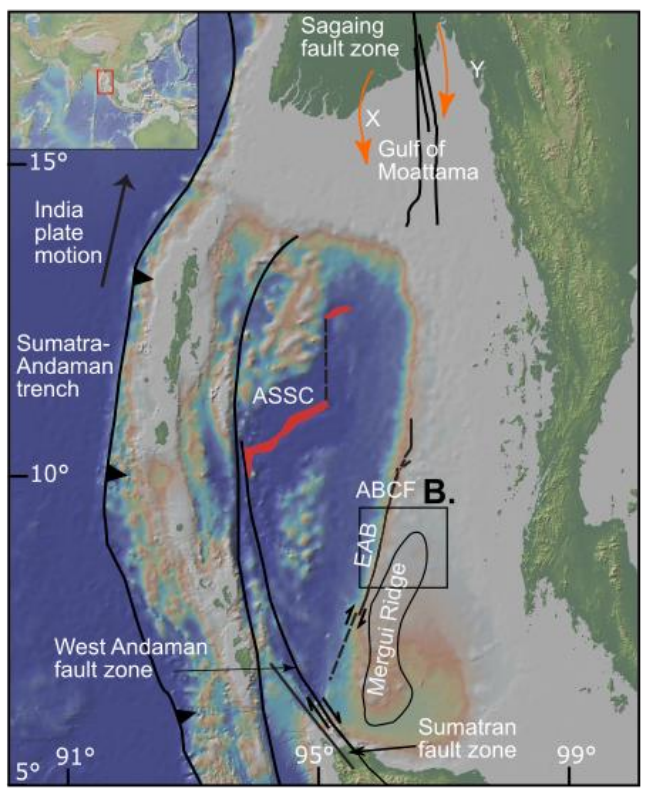

B. Top basement depth

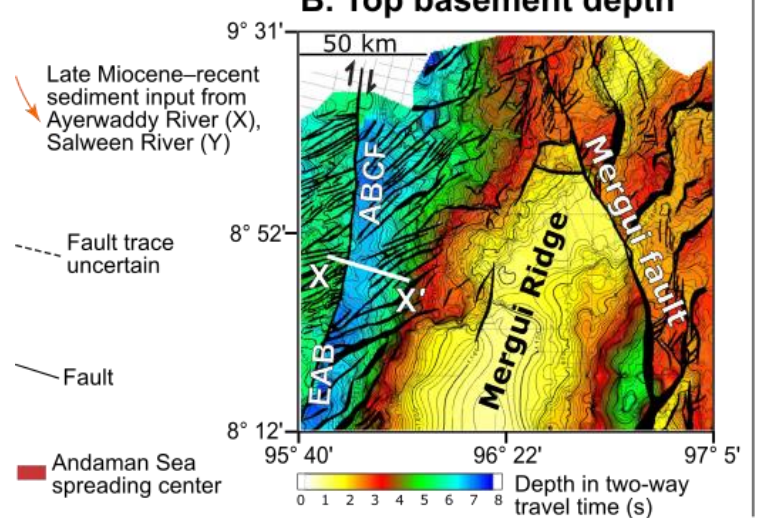

\section{East Andaman Basin (seismic)}
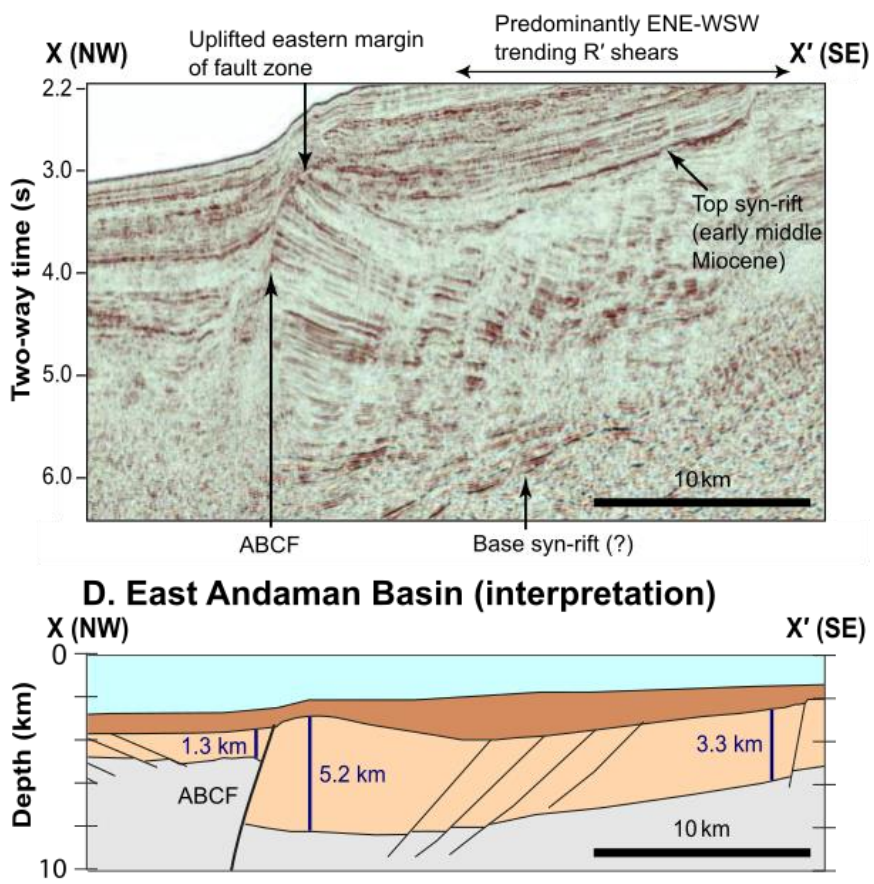

E. Reference model basin (10 m.y.)

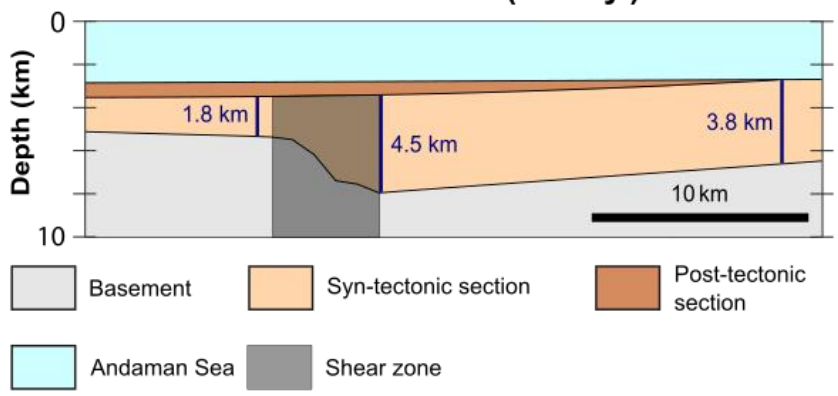

Figure 1. (A) Andaman Sea map. ASSC - Andaman Sea spreading center; ABCF-Andaman Basin Central fault; EAB - East Andaman Basin. (B) Depth to the top of the basement in two-way travel time. (C) Seismic data of the EAB. See B for profile location. (D) Depth interpretation of C. (E) Modeled basin. Post-tectonic sediment is computed by adding basement subsidence from 5 to $10 \mathrm{~m} . \mathrm{y}$. to the topography at $5 \mathrm{~m} . \mathrm{y}$.

During the Cenozoic, the Andaman Sea formed a transtensional backarc basin when India coupled with western Myanmar (Curray, 2005). Multiple strike-slip faults exist in the region, including the active, dextral, Sagaing fault (Fig. 1; 18 mm/yr: Vigny et al., 2003; Maurin et al., 2010) in the northeast of the Andaman Sea that connects southwestward to the Andaman spreading 
center (Curray, 2005). South of the Sagaing fault is the inactive Andaman Basin Central (strikeslip) fault (ABCF; Morley, 2016, 2017; Mahattanachai et al., 2021).

The Andaman Sea's transtensional motion led to subsidence and a submarine environment, causing the area to act as a sediment trap. Fault trends suggest the region near the ABCF experienced WNW-ESE extension in the Oligocene that shifted to NNW-SSE transtensional strike-slip motion during the early to mid-Miocene (lasting 5 m.y.; Morley, 2017). The ABCF follows a previous necking zone of hyperextended continental crust (7-10 km thick; Morley, 2017; Mahattanachai et al., 2021). During strike-slip motion, the easterly Mergui Ridge was partially subaerial and, along with peninsular Thailand, acted as an asymmetric clastic sediment source for the EAB located along the ABCF (Mahattanachai et al., 2021).

The geometry of the $\mathrm{EAB}$ in relation to the $\mathrm{ABCF}$ is described in detail by Mahattanachai et al. (2021), who concluded that the long ( $>200 \mathrm{~km})$, deep ( $>4 \mathrm{~km})$, westward-thickening basin on the east side of the sub-vertical fault did not fit classic extensional or pull-apart basin characteristics.

\section{MODEL SETUP AND EVOLUTION}

We reproduce the key aspects of the ABCF region, namely that of a submarine environment, thin lithosphere, and asymmetric sedimentation, using a viscoplastic $100 \times 8 \times 120 \mathrm{~km}(X, Y, Z)$ three-dimensional box model via a two-way coupling of the tectonic code ASPECT (https:// aspect.geodynamics.org, version 2.3.0-pre, commit 886749d) (Figs. 2B and 2C; Kronbichler et al., 2012; Heister et al., 2017; Glerum et al., 2018; Bangerth et al., 2019; Text S1 in the Supplemental Material) and the surface-processes code FastScape (https://fastscape.org) (Braun and Willett, 2013; Yuan et al., 2019b, 2019a; Text S2). We assume that a previous extensional event left the region submarine with thinned, $40-\mathrm{km}$-thick lithosphere. The model is initialized with $4 \mathrm{~km}$ of upper crust, $4 \mathrm{~km}$ of lower crust, $32 \mathrm{~km}$ of mantle lithosphere, and $80 \mathrm{~km}$ of asthenosphere (Fig. 2B; Fig. S1 in the Supplemental Material). The eastern boundary (right edge in Fig. 2B) has no slip in any direction, the western boundary (left edge in Fig. 2B) has no slip in the $Z$ direction, 20 $\mathrm{mm} / \mathrm{yr}$ in the $Y$ direction to induce strike-slip motion, and is given a small $(0.2 \mathrm{~mm} / \mathrm{yr})$ extensional component in the $X$ direction that helps avoid bending-induced compression but does not affect the presented results (Fig. S2). To simulate an infinitely long strike-slip fault with minimal alongstrike variation, the northern and southern boundaries are periodic, in that any material advected out of the northern boundary will flow into the model from the southern boundary, or vice-versa. 

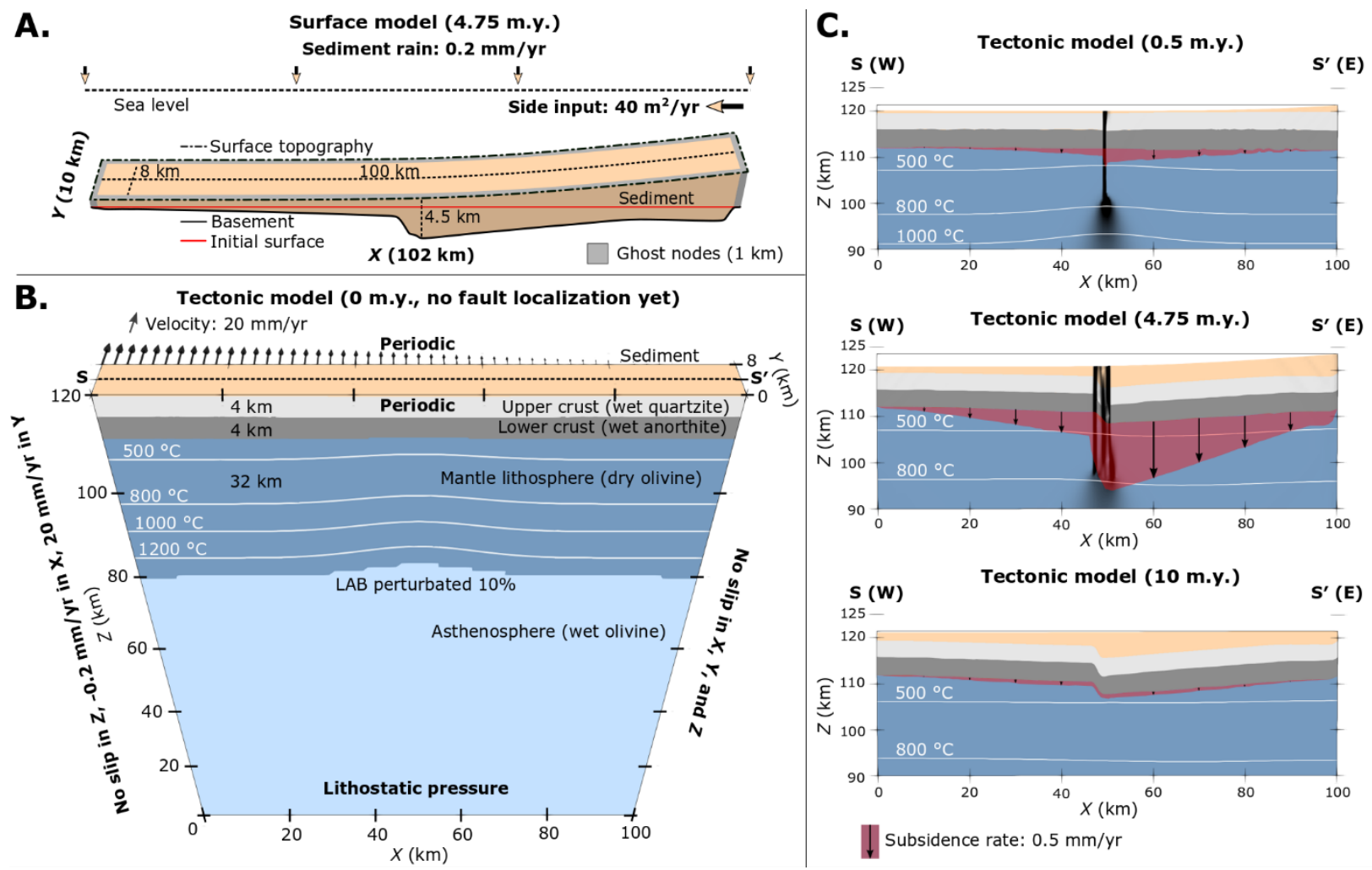

Figure 2. (A) Surface-processes model at $4.75 \mathrm{~m} . y$. and $2 \times$ vertical exaggeration. Sediment (beige) is the area between topography (dash-dot line) and basement (solid black line). Ghost nodes (gray) are a single cell-size $(1 \mathrm{~km}$ in $X$ and $Y$ ) layer surrounding the surface processes model implemented for periodic advection along the $Y$ direction and to control sedimentary side input, surround the surface model and do not interact with

the tectonic model. (B) Initial tectonic setup. Colors represent composition; white isotherms represent temperature distribution. Arrows indicate total velocity magnitude. The northern and southern boundaries are periodic, indicating that material flow out one boundary will become inflow on the opposing boundary. LAB - lithosphere-asthenosphere boundary. (C) Cross sections of the top $30 \mathrm{~km}$ of the tectonic model along $\mathrm{S}-\mathrm{S}^{\prime}$ in B showcase the formation of a flexural strike-slip basin in response to sedimentation. Subsidence rate at the Moho is indicated in red. See Movies S1 and S2 in the Supplemental Material.

The initial lithostatic pressure at a reference location is prescribed on the bottom boundary to allow for outflow in response to sedimentation. The strike-slip fault forms self-consistently above an initial perturbation of the lithosphere-asthenosphere boundary (10\% reduction of lithosphere thickness) in the center of the model that acts as a weak zone for deformation to localize. Accumulated plastic strain over an interval of $0-1$ weakens the angle of friction from an initial value of $30^{\circ}$ to a final value of $7.5^{\circ}$, promoting brittle localization.

The surface-processes code FastScape is coupled to the top of the tectonic model (Text S3). The model is submarine and sediment is transported via diffusion with a coefficient of $500 \mathrm{~m}^{2} / \mathrm{yr}$, consistent with open-marine environments in previous modeling studies (Rouby et al., 2013). Sediment is supplied to the domain in two ways: (1) the entire surface experiences $0.2 \mathrm{~mm} / \mathrm{yr}$ of pelagic and/or hemipelagic "sediment rain" sedimentation; and (2) ghost nodes (Fig. 2A) at the 
119 eastern boundary are uplifted each time step to prescribe a constant sediment flux of $40 \mathrm{~m}^{2} / \mathrm{yr}$,

120 mimicking an off-model sediment source similar to the Mergui Ridge for the EAB.

121 The models are run for 10 m.y., where the first 5 m.y. represent the syn-tectonic stage with 122 strike-slip motion and sedimentation to mimic the $\sim 5$ m.y. during which the ABCF was active.

123 The final 5 m.y. constitute the post-tectonic stage with no prescribed motion or sediment supply, 124 although sediment transport continues (for setup details, see Text S4).

125 REFERENCE MODEL RESULTS

126 In the reference model, strain localizes on a vertical fault near the model center (at $\sim 0.5$ m.y.; 127 Fig. 2C). Both sides of the fault subside due to the influx of sediment, with the eastern side sinking 128 faster (1.0 versus $0.4 \mathrm{~mm} / \mathrm{yr}$ at $4.75 \mathrm{~m} . \mathrm{y}$.). By $5 \mathrm{~m} . \mathrm{y}$., the eastern side has subsided more than the 129 western side (3.6 versus $1.0 \mathrm{~km}$ ), rotating the strike-slip fault to subvertical. After strike-slip 130 motion and sedimentation have ceased, the subsidence rate declines to $0.08 \mathrm{~mm} / \mathrm{yr}$ as the sediment 131 hill at the eastern boundary is distributed across the surface. By 10 m.y., both sides have subsided 132 another $0.4 \mathrm{~km}$, showing a synformal thickening geometry along the fault.

133 The model indicates that a flexural strike-slip basin emerges due to sedimentation above thin 134 lithosphere close to a strike-slip fault, wherein the fault acts as a weak zone where subsidence 135 focuses. In contrast to classical half-graben or pull-apart geometries, these basins form without a 136 significant extensional component (i.e., without crustal thinning as seen in pull-apart basins).

\section{CONTROLS ON FLEXURAL STRIKE-SLIP BASIN FORMATION}

138 To test controls on flexural strike-slip basin formation, we ran a series of models varying in 139 sedimentation rate, lithospheric thickness, and fault strength. Sedimentation rate was changed by 140 altering the eastern-side influx from 0 (i.e., only sediment rain) to $60 \mathrm{~m}^{2} / \mathrm{yr}$ (Figs. 3A-3D). With 141 no lateral input, both sides subsided evenly, forming a synformal basin that is thickest at the fault

142 (Fig. 3A). This suggests that reference-model basin asymmetry is affected primarily by 143 sedimentation and not by the initial perturbation. At higher lateral input, the eastern side subsided 144 more, from a maximum basement deflection of $0.9 \mathrm{~km}$ with no input to $5.7 \mathrm{~km}$ for $60 \mathrm{~m}^{2} / \mathrm{yr}$ of 145 input (Fig. 3D). The western side shows a less-pronounced deflection with higher sediment input $146(0.8-1.6 \mathrm{~km})$, suggesting either that the sides are not fully decoupled or that more sediment reached 147 the western side. 
The effects of varying the lithospheric thickness from 60 to $30 \mathrm{~km}$ (Figs. 3E-3H) reduce the basement flexural deflection on the eastern side of the fault from $4.6 \mathrm{~km}$ at $30 \mathrm{~km}$ to $1.4 \mathrm{~km}$ at 60 $\mathrm{km}$, suggesting that deep flexural basins are unlikely to form in regions with thick lithosphere.

The final key variable is friction-angle weakening (Figs. 3I-3L). This shows that fault strength 152 affects flexural subsidence (4.2 versus $3.3 \mathrm{~km}$ deflection at $99 \%$ and $25 \%$ weakening, 153 respectively), suggesting that regions with no weakening or without strike-slip motion (Fig. S3) 154 would experience much less subsidence. Further, weak faults promote lithospheric decoupling and 155 basin asymmetry related to asymmetric sedimentation.

Increasing sedimentation $\longrightarrow$
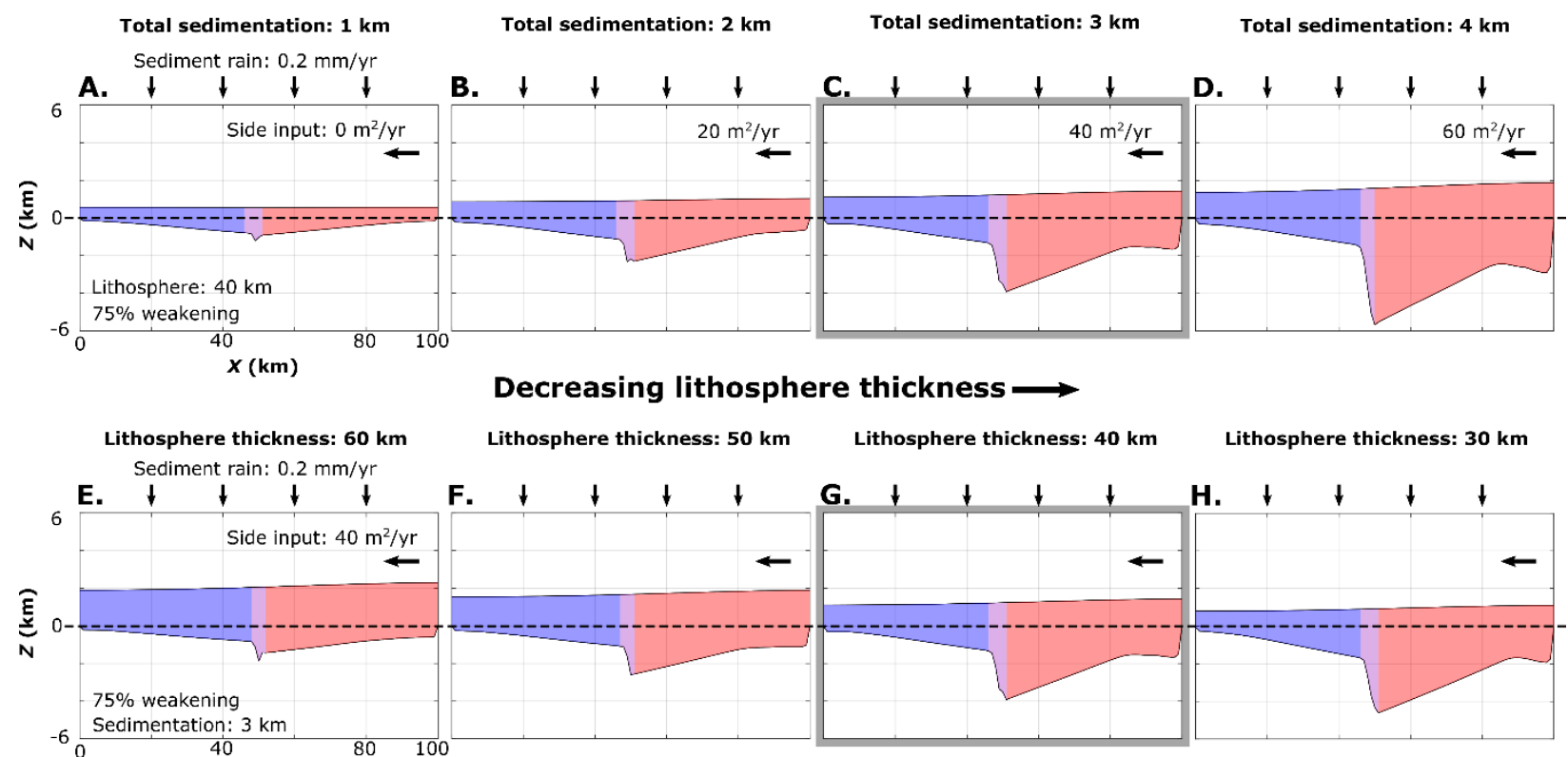
Increasing friction angle weakening $\longrightarrow$

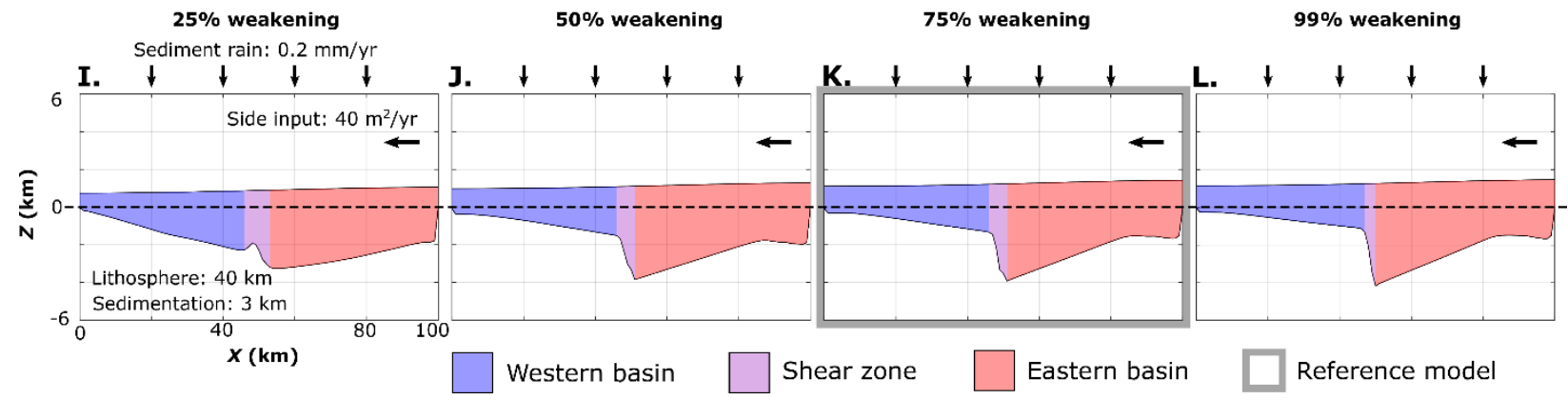

Figure 3. Modeled basin formation when subject to variable sediment input (A-D), lithosphere thickness (Esediment thickness assuming an even distribution across the model. 


\section{FLEXURAL STRIKE-SLIP BASINS IN THE ANDAMAN SEA}

Seismic data suggest that the EAB is an asymmetric basin that spans both sides of the ABCF (Mahattanachai et al., 2021). On the western side, basin thickness is fairly uniform (1-2 km; Fig. 1D). Along the fault on the eastern side, the basin is substantially thicker $(\sim 5 \mathrm{~km})$ and thins eastward toward the sediment source areas of the Mergui Ridge and peninsular Thailand.

The Gulf of Moattama Basin formed along the active Sagaing fault and is a more ambiguous example where a deep (>10 km) depocenter formed in the past $\sim 6$ m.y., although strike-slip fault activity in the area probably dates to the Oligocene (Morley and Arboit, 2019). Although a gentle releasing-bend geometry is present in the offshore fault trace, the basin did not undergo dramatic subsidence until the latest Miocene-Pliocene, when a major transgression followed structural uplift and inversion of basins onshore (e.g., Morley and Alvey, 2015). We suggest the axial sediment influx along the Gulf of Moattama Basin resulted in the flexural strike-slip mechanism enhancing the effects of the fault geometry.

The primary requirement for flexural strike-slip basin formation is weak or thin lithosphere and high sedimentation rates. There are two basin types, controlled by the sedimentation pattern: (1) symmetric, where both sides receive a similar sediment load (Fig. 3A); and (2) asymmetric, where the two distinct basin sides subside at different rates dependent on the sediment load they receive (Fig. 3C). In both types, the maximum flexure and basin depocenter occur along the fault trace and the basin thins strike-perpendicularly.

The Andaman Sea provides likely examples for each flexural strike-slip basin type:

(1) The Gulf of Moattama Basin, where northern axial sedimentation provided even sedimentation to each side of the fault and formed a symmetric flexural basin. While sedimentation was not purely uniform, a synformal geometry developed centered along the fault zone, as in Figure 3A.

(2) The EAB (Fig. 1D), where perpendicular sedimentation from the east forced greater flexure on the eastern side of the fault, forming an asymmetric flexural basin. The EAB and reference model basin both have a change in sediment thickness across the fault and basin thinning toward the sediment source. Furthermore, basin thicknesses (excluding post-tectonic sediment) along the 
188 fault's eastern side (4.5 versus $5.2 \mathrm{~km}$ in the model and EAB, respectively) and western side (1.8 189 versus $1.3 \mathrm{~km}$ ) are comparable between the model and the basin.

190 Despite the similarities, there are discrepancies between the modeled basin and the EAB. 191 Eastward thinning of the sediment layer is less pronounced in the model. Given that the basement 192 slope is affected by the lithosphere thickness and sediment load, three possible explanations are:

193 (1) The ABCF is capped by a regional unconformity with the post-tectonic sediments 194 (Srisuriyon and Morley, 2014; Morley, 2017), and the fault may have received more sediment 195 while active than expected from the seismic data.

196 (2) Given that the fault formed within a necking zone and the lithosphere thickness is not well 197 constrained, the lithosphere may have varied spatially (rheologically or in thickness) and been 198 thinner than the $40 \mathrm{~km}$ value used here.

199 (3) A more significant syn-strike-slip extensional component would have further deepened the 200 basin along the fault (Sobolev et al., 2005).

201 Also, our models do not consider basin translation with strike-slip motion. This is justified by 202 comparison with the EAB, where the thicker eastern basin is located on the same side as the Mergui 203 Ridge and is not affected by the translation. For the western basin, the $\sim 350$-km-long Mergui 204 Ridge is longer than the total dextral strike-slip translation of $\sim 90 \mathrm{~km}$ from the early to mid205 Miocene.

206 We focused on the Andaman Sea, but the key requirements for flexural strike-slip basins-thin 207 lithosphere, focused sedimentation, and a weak fault - are possibly also met in the New Guinea 208 Basin in the Bismarck Sea (southwestern Pacific Ocean; Fig. S4; Martinez and Taylor, 1996) and 209 the Yinggehai Basin in the South China Sea (Fig. S5; Clift and Sun, 2006), although new seismic 210 data are needed to test this. Another candidate is the Navassa Basin in the Jamaica Passage 211 (Caribbean Sea; Fig. S6; Corbeau et al., 2016), an asymmetric strike-slip basin that is not located 212 between offset segments. The basin likely formed during strike-slip motion and does not contain 213 older sedimentary units found in nearby basins along the fault. 


\section{CONCLUSION}

Our study suggests a new class of flexural basins that form along strike-slip faults. These basins are characterized by a fault-parallel depocenter and sediment that thins strike-perpendicularly. The basins can be classified in two types, which are both represented in the Andaman Sea: (1) symmetric flexural basins, where axial sedimentation causes a synformal shape, as seen in the Gulf of Moattama Basin; and (2) asymmetric flexural basins, where asymmetric sedimentation forces one basin side to subside more than the other, as seen in the EAB.

Flexural strike-slip basins form due to a strike-slip fault that acts as a weak zone facilitating differential subsidence due to sediment loading. The fault decouples the lithosphere sides, allowing them to respond independently to the sediment load they receive, determining basin symmetry. For a flexural strike-slip basin to form, two criteria must be met: the strike-slip fault must (1) cut through thin lithosphere, and (2) be subjected to a sufficient tectonic load.

\section{ACKNOWLEDGMENTS}

This study was conducted within the Helmholtz Young Investigators Group CRYSTALS (grant VH-NG-1132). We thank the Computational Infrastructure for Geodynamics (https://geodynamics.org/), which is funded by the U.S. National Science Foundation under awards EAR-0949446 and EAR-1550901, for supporting the development of ASPECT code. The work was supported by the North-German Supercomputing Alliance (HLRN, https://www.hlrn.de/). Software and input files are found at http://doi.org/10.5281/zenodo.4893421. Figures were made using ParaView, InkScape, and GeoMapApp. We also thank Anthony Jourdon, Zhen Sun, and an anonymous reviewer for their helpful reviews.

\section{REFERENCES}

Allen, P.A., and Allen, J.R., 2013, Basin Analysis 3rd edition:, doi:10.1017/CBO9781107415324.004.

Bangerth, W., Dannberg, J., Gassmoeller, R., and Heister, T., 2019, ASPECT v2.1.0: Zenodo, https://doi.org/10.5281/zenodo.2653531.

Braun, J., and Willett, S.D., 2013, A very efficient O(n), implicit and parallel method to solve the stream power equation governing fluvial incision and landscape evolution: Geomorphology, v. 180-181, p. 170-179, doi:10.1016/J.GEOMORPH.2012.10.008.

Clift, P.D., Brune, S., and Quinteros, J., 2015, Climate changes control offshore crustal structure at South China Sea continental margin: Earth and Planetary Science Letters, v. 420, p. 66- 

72, doi:10.1016/j.epsl.2015.03.032.

Clift, P.D., and Sun, Z., 2006, The sedimentary and tectonic evolution of the Yinggehai-Song Hong basin and the southern Hainan margin, South China Sea: Implications for Tibetan uplift and monsoon intensification: Journal of Geophysical Research: Solid Earth, v. 111, p. 1-28, doi:10.1029/2005JB004048.

Corbeau, J., Rolandone, F., Leroy, S., Mercier de Lépinay, B., Meyer, B., Ellouz-Zimmermann, N., and Momplaisir, R., 2016, The northern Caribbean plate boundary in the Jamaica Passage: Structure and seismic stratigraphy: Tectonophysics, v. 675, p. 209-226, doi:10.1016/j.tecto.2016.03.022.

Curray, J.R., 2005, Tectonics and history of the Andaman Sea region: Journal of Asian Earth Sciences, v. 25, p. 187-232, doi:10.1016/j.jseaes.2004.09.001.

Dong, M., Zhang, J., Brune, S., Wu, S., Fang, G., and Yu, L., 2020, Quantifying Postrift Lower Crustal Flow in the Northern Margin of the South China Sea: Journal of Geophysical Research: Solid Earth, v. 125, doi:10.1029/2019JB018910.

Garfunkel, Z., and Ben-Avraham, Z., 1996, The structure of the Dead Sea basin: Tectonophysics, v. 266, p. 155-176, doi:10.1016/S0040-1951(96)00188-6.

Glerum, A., Thieulot, C., Fraters, M., Blom, C., and Spakman, W., 2018, Nonlinear viscoplasticity in ASPECT: Benchmarking and applications to subduction: Solid Earth, v. 9, p. 267-294, doi:10.5194/se-9-267-2018.

Gurbuz, A., 2010, Geometric characteristics of pull-apart basins: Lithosphere, v. 2, p. 199-206, doi:10.1130/L36.1.

Heister, T., Dannberg, J., Gassmöller, R., and Bangerth, W., 2017, High Accuracy Mantle Convection Simulation through Modern Numerical Methods - II: Realistic Models and Problems.: Geophysical Journal International, v. 210, p. 833-851, doi:doi:10.1093/gji/ggx 195 .

Jourdon, A., Kergaravat, C., Duclaux, G., and Huguen, C., 2021, Looking beyond kinematics: 3D thermo-mechanical modelling reveals the dynamics of transform margins: Solid Earth, v. 12, p. 1211-1232, doi:10.5194/se-12-1211-2021.

Kronbichler, M., Heister, T., and Bangerth, W., 2012, High Accuracy Mantle Convection Simulation through Modern Numerical Methods.: Geophysical Journal International, v. 191, doi:doi:10.1111/j.1365-246x.2012.05609.x.

Mahattanachai, T., Morley, C.K., Charusiri, P., and Kanjanapayont, P., 2021, The Andaman Basin Central Fault Zone, Andaman Sea: Characteristics of a major deepwater strike-slip fault system in a polyphase rift: Marine and Petroleum Geology, p. 104997, doi:10.1016/j.marpetgeo.2021.104997.

Mann, P., Hempton, M.R., Dwight, C.B., and Burke, K., 1983, Development of Pull-Apart Basins Authors: Paul Mann, Mark R . Hempton, Dwight C . Bradley and Kevin Burke Published by: The University of Chicago Press Stable URL: http://www.jstor.org/stable/30064017 . All use subject to JSTOR Terms and Conditio: The Journal of Geology, v. 91, p. 529-554. 
Martinez, F., and Taylor, B., 1996, Backarc spreading, rifting, and microplate rotation, between transform faults in the Manus Basin: Marine Geophysical Researches, v. 18, p. 203-224, doi:10.1007/BF00286078.

Maurin, T., Masson, F., Rangin, C., Min, U.T., and Collard, P., 2010, First global positioning system results in northern Myanmar: Constant and localized slip rate along the Sagaing fault: Geology, v. 38, p. 591-594, doi:10.1130/G30872.1.

Morley, C.K., 2017, Cenozoic rifting, passive margin development and strike-slip faulting in the Andaman Sea: A discussion of established v. New tectonic models: Geological Society Memoir, v. 47, p. 27-50, doi:10.1144/M47.4.

Morley, C.K., 2016, The impact of multiple extension events, stress rotation and inherited fabrics on normal fault geometries and evolution in the Cenozoic rift basins of Thailand: Geological Society, London, Special Publications, v. 439, p. 413-445, doi:https://doi.org/10.1144/SP439.3.

Morley, C.K., and Alvey, A., 2015, Is spreading prolonged, episodic or incipient in the Andaman Sea? Evidence from deepwater sedimentation: Journal of Asian Earth Sciences, v. 98, p. 446456, doi:10.1016/j.jseaes.2014.11.033.

Morley, C.K., and Arboit, F., 2019, Dating the onset of motion on the Sagaing fault: Evidence from detrital zircon and titanite U-Pb geochronology from the North Minwun Basin, Myanmar: Geology, v. 47, p. 581-585, doi:10.1130/G46321.1.

Morley, C.K., and Westaway, R., 2006, Subsidence in the super-deep Pattani and Malay basins of Southeast Asia: A coupled model incorporating lower-crustal flow in response to post-rift sediment loading: Basin Research, v. 18, p. 51-84, doi:10.1111/j.1365-2117.2006.00285.x.

Provost, A.-S., and Houston, H., 2003, Stress orientations in northern and central California: Evidence for the evolution of frictional strength along the San Andreas plate boundary system: Journal of Geophysical Research: Solid Earth, v. 108, p. 1-18, doi:10.1029/2001jb001123.

Rouby, D., Braun, J., Robin, C., Dauteuil, O., and Deschamps, F., 2013, Long-term stratigraphic evolution of Atlantic-type passive margins: A numerical approach of interactions between surface processes, flexural isostasy and 3D thermal subsidence: Tectonophysics, v. 604, p. 83-103, doi:10.1016/j.tecto.2013.02.003.

Seeber, L., Emre, O., Cormier, M.H., Sorlien, C.C., McHugh, C.M.G., Polonia, A., Ozer, N., and Cagatay, N., 2004, Uplift and subsidence from oblique slip: The Ganos-Marmara bend of the North Anatolian Transform, Western Turkey: Tectonophysics, v. 391, p. 239-258, doi:10.1016/j.tecto.2004.07.015.

SERPA, L., DE VOOGD, B., WRIGHT, L., WILLEMIN, J., OLIVER, J., HAUSER, E., and TROXEL, B., 1988, Structure of the central Death Valley pull-apart basin and vicinity from COCORP profiles in the southern Great Basin: GSA Bulletin, v. 100, p. 1437-1450, doi:10.1130/0016-7606(1988)100<1437:SOTCDV>2.3.CO;2.

Sobolev, S. V., Petrunin, A., Garfunkel, Z., and Babeyko, A.Y., 2005, Thermo-mechanical model of the Dead Sea Transform: Earth and Planetary Science Letters, v. 238, p. 78-95, 
doi:10.1016/j.eps1.2005.06.058.

325

326

327

328

329

330
Srisuriyon, K., and Morley, C.K., 2014, Pull-apart development at overlapping fault tips: Oblique rifting of a Cenozoic continental margin, northern Mergui Basin, Andaman Sea: Geosphere, v. 10, p. 80-106, doi:10.1130/GES00926.1.

Vigny, C., Socquet, A., Rangin, C., Chamot-Rooke, N., Pubellier, M., Bouin, M.-N., Bertrand, G., and Becker, M., 2003, Present-day crustal deformation around Sagaing fault, Myanmar: Journal of Geophysical Research: Solid Earth, v. 108, doi:https://doi.org/10.1029/2002JB001999.

van Wijk, J., Axen, G., and Abera, R., 2017, Initiation, evolution and extinction of pull-apart basins: Implications for opening of the Gulf of California: Tectonophysics, v. 719-720, p. 37-50, doi:10.1016/j.tecto.2017.04.019.

Yuan, X.P., Braun, J., Guerit, L., Rouby, D., and Cordonnier, G., 2019a, A New Efficient Method to Solve the Stream Power Law Model Taking Into Account Sediment Deposition: Journal of Geophysical Research: Earth Surface, v. 124, p. 1346-1365, doi:10.1029/2018JF004867.

Yuan, X.P., Braun, J., Guerit, L., Simon, B., Bovy, B., Rouby, D., Robin, C., and Jiao, R., 2019b, Linking continental erosion to marine sediment transport and deposition: A new implicit and $\mathrm{O}(\mathrm{N})$ method for inverse analysis: Earth and Planetary Science Letters, v. 524, p. 115728, doi:10.1016/j.epsl.2019.115728.

Zoback, M.D. et al., 1987, New evidence on the state of stress of the san andreas fault system: Science, v. 238, p. 1105-1111, doi:10.1126/science.238.4830.1105. 


\section{Supplementary Information}

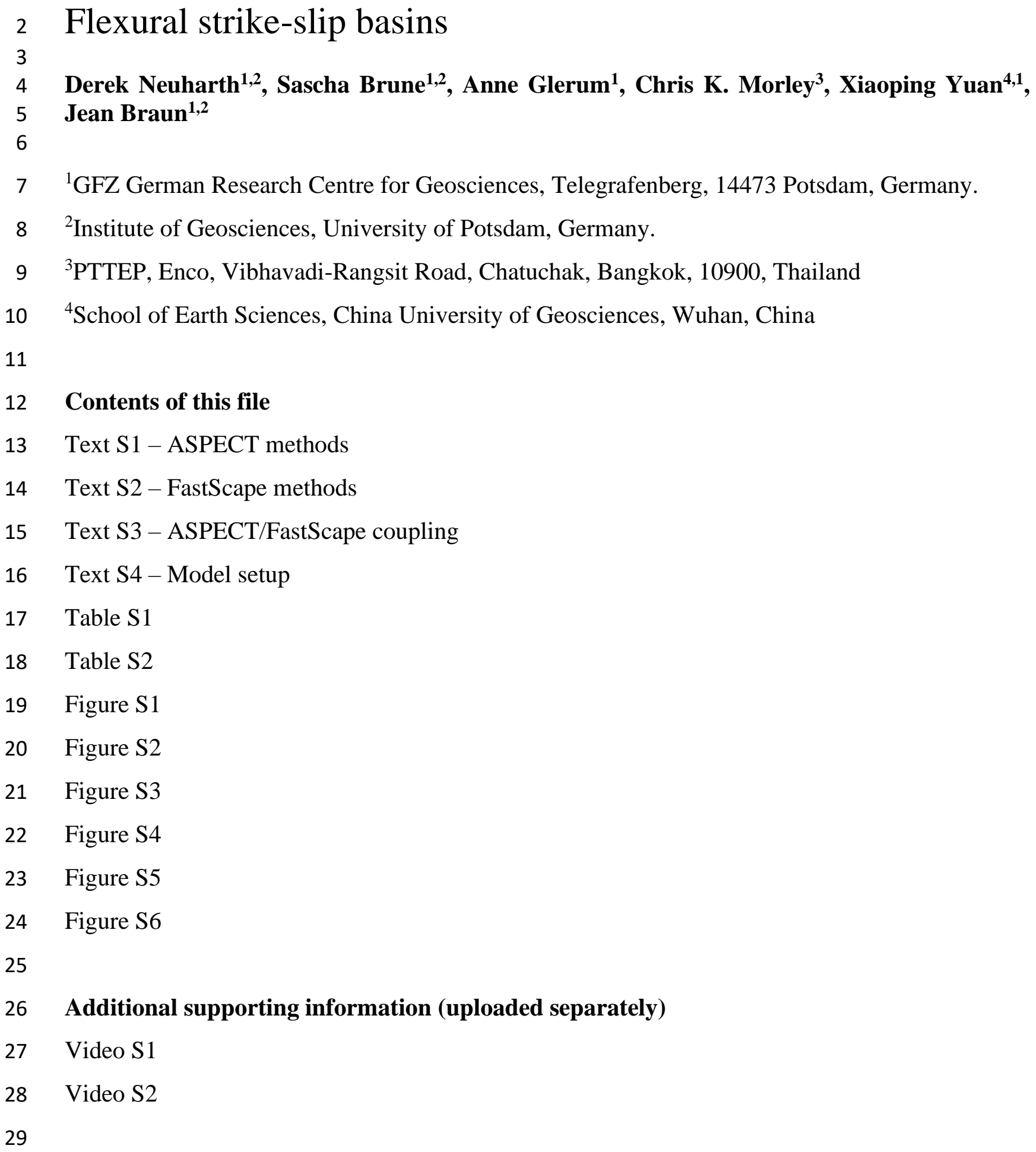


47

\section{Text S1: ASPECT Methods}

\subsection{Governing equations}

We perform numerical simulations of a 3D strike-slip system using the open source finite-element code ASPECT (Advanced Solver for Problems in Earth's ConvecTion, version 2.3.0-pre, commit 886749d; Heister et al., 2017; Kronbichler et al., 2012; Rose et al., 2017; Bangerth et al., 2019). ASPECT solves the following incompressible conservation equations assuming an infinite Prandtl number (i.e., without the inertial term),

$$
-\nabla \cdot(2 \eta \dot{\varepsilon})+\nabla \mathrm{P}=\rho \mathbf{g}
$$

$$
\bar{\rho} C_{p}\left(\frac{\partial T}{\partial t}+\mathbf{u} \cdot \nabla \mathrm{T}\right)-\nabla \cdot k \nabla T=\bar{\rho} \mathrm{H}
$$$$
+\alpha \mathrm{T}(\mathbf{u} \cdot \nabla \mathrm{P})
$$

$$
\frac{\partial c_{i}}{\partial t}+\mathbf{u} \cdot \nabla c_{i}=q_{i}
$$

where equation (1) represents the conservation of momentum, with $\eta$ the effective viscosity, $\dot{\varepsilon}$ the deviator of the strain rate tensor (defined as $\frac{1}{2}\left(\nabla \mathbf{u}+(\nabla \mathbf{u})^{\mathrm{T}}\right)$ ), $\mathbf{u}$ the velocity, $\mathrm{P}$ the pressure, $\rho$ the density, and g gravity. Equation (2) describes the conservation of volume. Equation (3) represents the conservation of energy where $\bar{\rho}$ is the reference adiabatic density, $C_{p}$ the specific heat capacity, $\mathrm{T}$ the temperature, $\mathrm{k}$ the thermal conductivity, $\mathrm{H}$ the radiogenic heating, and $\alpha$ the thermal expansivity. As right-hand-side heating terms, we include radioactive heating and adiabatic heating, in that order. Finally, we solve the advection equation (4) for each compositional field $c_{i}$

9 (e.g., upper crust, lower crust, and accumulated plastic strain) with reaction rate $\mathrm{q}_{\mathrm{i}}$ nonzero only for the plastic strain field. 


\section{$51 \quad \mathbf{1 . 2}$ Rheology}

52 We use a visco-plastic rheology (Glerum et al., 2018), which additionally includes plastic

53 weakening based on accumulated plastic strain. In the viscous regime, we use a composite of 54 diffusion and dislocation creep (Karato and $\mathrm{Wu}, 1993)$, formulated as:

$$
\eta_{\text {eff }}^{\text {diff } \mid \text { dis }}=\frac{1}{2} A_{\text {diff } \mid \text { dis }}^{\frac{-1}{n}} d^{m^{2}} \frac{1-n}{\dot{\varepsilon}_{e}} \exp \left(\frac{\left(E_{\text {diff } \mid \text { dis }}+P V_{\text {diff } \mid \text { dis }}\right)}{n R T}\right)
$$

where $\mathrm{A}$ is a scalar prefactor, $\mathrm{d}$ the grain size, $\dot{\varepsilon}_{\mathrm{e}}$ the square root of second invariant of the

57 deviatoric strain rate, $\mathrm{E}$ the activation energy, $\mathrm{P}$ the pressure, $\mathrm{V}$ the activation volume, $\mathrm{R}$ the gas

58 constant, $\mathrm{T}$ the temperature, and $\mathrm{n}$ the stress exponent. For diffusion, $\mathrm{n}=1$ and the equation

59 becomes independent of strain rate. For dislocation creep, the grain size exponent $m$ vanishes, 60 rendering dislocation creep independent of grain size. Values for A, E, V, and n used in our models 61 are composition-dependent and can be found in supplementary Table S1.

62 In the plastic regime, when viscous stresses exceed the yield stress, we use the Drucker-Prager 63 yield criterion (Davis and Selvadurai, 2002). The effective plastic viscosity is given by

$$
\eta_{\mathrm{eff}}^{\mathrm{pl}}=\frac{\frac{6 \mathrm{C} \cos \phi}{\sqrt{3}(3-\sin \phi)}+\frac{6 \mathrm{P} \sin \phi}{\sqrt{3}(3-\sin \phi)}}{2 \dot{\varepsilon}_{\mathrm{e}}},
$$

65 where $\mathrm{C}$ is the cohesion and $\phi$ the internal angle of friction. The accumulation of plastic strain is tracked as a compositional field. This field is used to linearly weaken $\phi$ from an initial value of

$6730^{\circ}$ to a final value of $7.5^{\circ}$ over the accumulated plastic strain interval of 0 to 1 . The time-integrated 68 value of the strain reaction rate $\mathrm{q}_{\mathrm{i}}$ is approximated as $\dot{\varepsilon}_{\mathrm{e}} \cdot \mathrm{dt}$ when plastic yielding occurs (with dt 69 the current timestep size). 
71

72

73

74

75

76

77

78 79 only as

80

81 where $\mathrm{h}$ is the topographic elevation, $\mathbf{U}$ the uplift rate and $\mathrm{K}_{\mathrm{m}}$ the marine sediment diffusion

82

\section{Text S2: FastScape Methods}

FastScape is a landscape evolution code that changes the topographic surface through uplift, advection, the stream-power law, and hillslope diffusion (Braun and Willett, 2013). It can additionally deposit fluvial sediment (Yuan et al., 2019a) and include a marine component, which handles marine sediment (sand/silt) transport and deposition, and layer compaction based on sand/silt porosity (Yuan et al., 2019b). It uses a 2D horizontal mesh with a uniform resolution. For simplicity, we here assume that the entire model surface is submarine, with uniform properties (i.e., sand and silt transport coefficients are the same), and that there is no compaction (porosity is zero). Hence, FastScape deforms the surface through the uplift rate and marine diffusion equation

$$
\text { coefficient. }
$$

\section{Text S3: ASPECT/FastScape coupling}

In this paper we use a two-way coupling of the tectonic ASPECT code and the landscape evolution FastScape code. For this coupling, a FastScape shared library is called by an ASPECT plugin to deform its surface as described in the previous section. The plugin has three main components: 1) Copy the surface height and velocity values from ASPECT. 2) Initialize and run FastScape at a resolution equivalent to or greater than the one used at the surface of ASPECT. If it is the first timestep of the tectonic model run, FastScape is initialized using height and velocity values from ASPECT. In subsequent timesteps, as FastScape runs separately and can be at a higher resolution than ASPECT, only the velocity values from ASPECT are transferred to FastScape. Before 
92 running FastScape, the initial topography values are saved. After running FastScape, the new and

93 previous topography are compared to determine a nodal vertical (Z) velocity,

$$
\mathbf{V}_{\mathbf{z}}=\frac{\mathrm{h}_{\mathrm{c}}-\mathrm{h}_{\mathrm{p}}}{\mathrm{dt}_{\mathrm{a}}}
$$

95 102 again.

where $h_{p}$ is the surface height at the start of the timestep (previous surface), and $h_{f}$ the surface height after FastScape has been run (current surface), and $\mathrm{dt}_{\mathrm{a}}$ the ASPECT timestep. 3) Using the overarching mesh deformation functionality (see Rose et al., 2017), the $\mathrm{Z}$ velocity field is interpolated onto the ASPECT surface to determine the displacement of the mesh surface and interior. From there, ASPECT responds to the change in topography calculated by FastScape due to the induced change in forces that is included in the Stokes equations. At the beginning of the next timestep, the updated velocities computed in the previous timestep are sent to FastScape once

The FastScape mesh includes an additional element-size layer of ghost nodes compared to the ASPECT surface mesh. The values of surface height on these nodes are not considered when interpolating the surface back to ASPECT and are used primarily to avoid FastScape boundary artifacts being sent to the ASPECT model (e.g., the boundaries do not uplift from advected topography). To avoid possible erroneous sediment flux out or into the model from artificial slopes, each timestep the ghost nodes are updated with the topography and velocity values of the nearest inward node (an ASPECT boundary node).

Besides passing ASPECT's uplift velocities, we use the plugin's FastScape interface to supply additional input to the surface process model in two ways: 1) to add marine background sedimentation via the sediment rain effect, and 2) to add a boundary sediment flux using the ghost nodes. For the sediment rain, at each nodal point we update FastScape with a flat height increase 
114 every ASPECT timestep. Through the diffusion component in equation (7), we prescribe a constant 115 sediment flux at the boundary, assuming that

$$
\mathbf{Q}=\mathrm{K}_{\mathrm{m}} \mathrm{S},
$$

117 where $\mathbf{Q}$ is the sediment flux and $\mathrm{S}$ the slope. Since $\mathrm{K}_{\mathrm{m}}$ and $\mathrm{Q}$ are user-set parameters, to achieve 118 this we alter $\mathrm{S}$ by uplifting the boundary ghost nodes every ASPECT timestep so that $\mathbf{Q}$ remains 119 constant.

\section{Text S4: Model setup}

121 In this study we examine how a strike-slip fault responds to sedimentation. We therefore set up a 122 3D box model with dimensions $100 \times 8 \times 120 \mathrm{~km}$ (X, Y, and $\mathrm{Z}$, where $\mathrm{Z}$ is the vertical component) 123 and 5 compositions representing a wet quartzite upper crust (Rutter and Brodie, 2004), wet 124 anorthite lower crust (Rybacki et al., 2006), dry olivine lithospheric mantle, wet olivine 125 asthenosphere (Hirth and Kohlstedt, 2003), and a sediment layer that has rheologic parameters 126 identical to wet quartzite, but with density and temperature parameters consistent with sediment 127 (Sippel et al., 2017). The total crustal thickness is set to $8 \mathrm{~km}$ (4 km upper crust, $4 \mathrm{~km}$ lower crust) 128 based on crustal estimates of the area (7-10 km; Mahattanachai et al., 2021). The lithospheric 129 mantle extends between the Moho and the lithosphere-asthenosphere boundary (LAB) at $40 \mathrm{~km}$ 130 depth. The LAB depth, like the crust, has been perturbed by a previous extensional period. The 131 remaining material beneath the LAB is considered asthenosphere (Fig. S1). While there is no initial 132 sediment layer, the top boundary is fixed to a sediment composition so that any top-inflow of 133 material due to topography changes other than uplift is sediment.

134 The ASPECT model mesh consists of two element sizes: $1 \mathrm{~km}$ and $2 \mathrm{~km}$. The upper $8 \mathrm{~km}$ of the 135 model is refined at $1 \mathrm{~km}$ to best resolve the crust and the forming sediment layer. This high- 
136 resolution area additionally extends to a depth of $35 \mathrm{k}$ from $X=42 \mathrm{~km}$ to $X=52 \mathrm{~km}$ to better

137 resolve the strike-slip fault. All other areas are kept at $2 \mathrm{~km}$ resolution.

138 The initial temperature above the LAB is determined by a steady-state geotherm (Turcotte and 139 Schubert, 2013), and below by a mantle adiabat. For simplicity, an initial weak zone is seeded 140 through a small perturbation: we raise the LAB locally by $10 \%$ of the lithospheric mantle thickness. 141 We fix the top boundary temperature at $0{ }^{\circ} \mathrm{C}$ and the bottom boundary at the temperature initially 142 determined from the mantle adiabat at that depth. All other boundaries are set to zero heat-flux.

143 The coupled model is run for $10 \mathrm{Myr}$, where the model in the first $5 \mathrm{Myr}$ includes non-zero velocity 144 boundary conditions. During this time, the western boundary is given a strike-slip component of $14520 \mathrm{~mm} / \mathrm{yr}$ (in Y), and an extensional component of $0.2 \mathrm{~mm} / \mathrm{yr}$ (in X), while the Z-component of 146 velocity is set to no-slip. This gives a total of $100 \mathrm{~km}$ of dextral strike-slip motion and $1 \mathrm{~km}$ of 147 extension. The small extensional component is introduced to avoid compressional pop-ups that 148 form at the shear zone as the lithosphere subsides due to the sediment load (Fig. S2). The exact 149 extensional value is chosen to accommodate horizontal stress forces related to isostatic 150 compensation. From 5-10 Myr, extension and strike-slip motion stop as the western boundary is 151 set to no-slip in all directions. All other boundary conditions are constant for the entire model run, 152 with the eastern boundary being no-slip in all directions, the north and south boundaries set to 153 periodic to simulate an infinitely long strike-slip fault, the initial lithostatic pressure computed at 154 a reference location prescribed on the bottom boundary to allow for outflow in response to 155 sedimentation, and the top boundary deformed through the use of FastScape.

156 FastScape is set up with an arbitrarily high sea level so that the entire model is considered 157 submarine. This setup leads to a model with no acting stream power law, and sediment being 158 moved solely through marine sediment diffusion. For simplicity, we additionally assume that there 
159 is no compaction and no difference between sand and silt. As such, we use a diffusion coefficient 160 of $500 \mathrm{~m}^{2} / \mathrm{y}$ for both, a value consistent with open marine environments in previous modelling 161 studies (e.g., Rouby et al., 2013). During the syn-strike-slip phase of the tectonic model (0-5 Myr) 162 we supply sediment to the model in two ways: 1) To account for pelagic/hemipelagic 163 sedimentation (sediment rain), we deposit at a constant and uniform sedimentation rate of 0.2 $164 \mathrm{~mm} / \mathrm{yr} .2$ ) We assume there is an asymmetric off-model source of sediment, similar to the eastern 165 Mergui Ridge for the East Andaman Basin, that inputs sediment into the system from the eastern 166 boundary at a rate of $40 \mathrm{~m}^{2} / \mathrm{yr}$. This is done through equation (9), wherein we uplift the ghost nodes 167 at each timestep so that a constant flux is prescribed through marine diffusion. After this syn168 tectonic stage spanning $5 \mathrm{Myr}$, sediment supply to the system is halted, although marine diffusion 169 continues to work on the topography. 


\begin{tabular}{|c|c|c|c|c|c|c|c|}
\hline Parameter & Symbol & Units & Sediment & $\begin{array}{l}\text { Upper } \\
\text { crust }\end{array}$ & $\begin{array}{l}\text { Lower } \\
\text { crust }\end{array}$ & $\begin{array}{l}\text { Lithospheric } \\
\text { mantle }\end{array}$ & Asthenosphere \\
\hline $\begin{array}{l}\text { Reference } \\
\text { density (at } \\
\text { surface } \\
\text { conditions) }\end{array}$ & $\rho_{0}$ & $\mathrm{~kg} \mathrm{~m}^{-3}$ & 2520 & 2700 & 2850 & 3280 & 3300 \\
\hline $\begin{array}{l}\text { Thermal } \\
\text { expansivity }\end{array}$ & $\alpha$ & $\mathrm{K}^{-1}$ & $3.7 \cdot 10^{-5}$ & $2.7 \cdot 10^{-5}$ & $2.7 \cdot 10^{-5}$ & $3.0 \cdot 10^{-5}$ & $3.0 \cdot 10^{-5}$ \\
\hline $\begin{array}{l}\text { Thermal } \\
\text { diffusivity }\end{array}$ & $\kappa$ & $\mathrm{m}^{2} \mathrm{~s}^{-1}$ & $7.28 \cdot 10^{-7}$ & $9.26 \cdot 10^{-7}$ & $5.85 \cdot 10^{-7}$ & $8.38 \cdot 10^{-7}$ & $8.33 \cdot 10^{-7}$ \\
\hline Heat capacity & $\mathrm{C}_{\mathrm{p}}$ & $\begin{array}{l}\mathrm{J} \quad \mathrm{kg}^{-1} \\
\mathrm{~K}^{-1}\end{array}$ & 1200 & 1200 & 1200 & 1200 & 1200 \\
\hline $\begin{array}{l}\text { Heat } \\
\text { production }\end{array}$ & $\mathrm{H}$ & $\mathrm{W} \mathrm{m} \mathrm{m}^{-3}$ & $1.2 \cdot 10^{-6}$ & $1.5 \cdot 10^{-6}$ & $0.2 \cdot 10^{-6}$ & 0 & 0 \\
\hline Cohesion & $\mathrm{C}$ & $\mathrm{Pa}$ & $20 \cdot 10^{6}$ & $20 \cdot 10^{6}$ & $20 \cdot 10^{6}$ & $20 \cdot 10^{6}$ & $20 \cdot 10^{6}$ \\
\hline $\begin{array}{l}\text { Internal } \\
\text { friction angle } \\
\text { (unweakened) }\end{array}$ & $\phi$ & $\circ$ & 30 & 30 & 30 & 30 & 30 \\
\hline $\begin{array}{l}\text { Strain } \\
\text { weakening } \\
\text { interval }\end{array}$ & - & - & {$[0,1]$} & {$[0,1]$} & {$[0,1]$} & {$[0,1]$} & {$[0,1]$} \\
\hline $\begin{array}{l}\text { Strain } \\
\text { weakening } \\
\text { factor }\end{array}$ & $\phi_{\mathrm{wf}}$ & - & 0.25 & 0.25 & 0.25 & 0.25 & 0.25 \\
\hline $\begin{array}{l}\text { Creep } \\
\text { properties }\end{array}$ & & & Sediment & $\begin{array}{l}\text { Wet } \\
\text { quartzite }\end{array}$ & $\begin{array}{l}\text { Wet } \\
\text { anorthite }\end{array}$ & Dry olivine & Wet olivine \\
\hline $\begin{array}{l}\text { Stress } \\
\text { exponent (dis) }\end{array}$ & $\mathrm{n}$ & - & 4.0 & 4.0 & 3.0 & 3.5 & 3.5 \\
\hline $\begin{array}{l}\text { Constant } \\
\text { prefactor } \\
\text { (dis) }\end{array}$ & $\mathrm{A}_{\mathrm{dis}}$ & $\mathrm{Pa}^{-\mathrm{n}} \mathrm{s}^{-1}$ & $8.57 \cdot 10^{-28}$ & $8.57 \cdot 10^{-28}$ & $7.13 \cdot 10^{-18}$ & $6.52 \cdot 10^{-16}$ & $2.12 \cdot 10^{-15}$ \\
\hline $\begin{array}{l}\text { Activation } \\
\text { energy (dis) }\end{array}$ & $\mathrm{E}_{\mathrm{dis}}$ & $\mathrm{J} \mathrm{mol}^{-1}$ & $223 \cdot 10^{3}$ & $223 \cdot 10^{3}$ & $345 \cdot 10^{3}$ & $530 \cdot 10^{3}$ & $480 \cdot 10^{3}$ \\
\hline $\begin{array}{l}\text { Activation } \\
\text { volume } \\
\text { (dis) }\end{array}$ & $\mathrm{V}_{\mathrm{dis}}$ & $\begin{array}{l}\mathrm{m}^{3} \\
\mathrm{~mol}^{-1}\end{array}$ & 0 & 0 & $38 \cdot 10^{-6}$ & $18 \cdot 10^{-6}$ & $11 \cdot 10^{-6}$ \\
\hline $\begin{array}{l}\text { Constant } \\
\text { prefactor } \\
\text { (diff) }\end{array}$ & $A_{\text {diff }}$ & $\mathrm{Pa}^{-1} \mathrm{~s}^{-1}$ & $5.79 \cdot 10^{-19}$ & $5.79 \cdot 10^{-19}$ & $2.99 \cdot 10^{-25}$ & $2.25 \cdot 10^{-9}$ & $1.5 \cdot 10^{-9}$ \\
\hline $\begin{array}{l}\text { Activation } \\
\text { energy (diff) }\end{array}$ & $E_{\text {diff }}$ & $\mathrm{J} \mathrm{mol}^{-1}$ & $223 \cdot 10^{3}$ & $223 \cdot 10^{3}$ & $159 \cdot 10^{3}$ & $375 \cdot 10^{3}$ & $335 \cdot 10^{3}$ \\
\hline $\begin{array}{l}\text { Activation } \\
\text { volume (diff) }\end{array}$ & $\mathrm{V}_{\text {diff }}$ & $\begin{array}{l}\mathrm{m}^{3} \\
\mathrm{~mol}^{-1}\end{array}$ & 0 & 0 & $38 \cdot 10^{-6}$ & $6 \cdot 10^{-6}$ & $4 \cdot 10^{-6}$ \\
\hline $\begin{array}{l}\text { Grain size } \\
\text { (diff) }\end{array}$ & $\mathrm{d}$ & $\mathrm{m}$ & 0.001 & 0.001 & 0.001 & 0.001 & 0.001 \\
\hline $\begin{array}{l}\text { Grain size } \\
\text { exponent } \\
\text { (diff) }\end{array}$ & $\mathrm{m}$ & - & 2.0 & 2.0 & 3.0 & 0 & 0 \\
\hline
\end{tabular}

171 Table S1: ASPECT model parameters. Abbreviations: dis - dislocation creep, diff - diffusion 172 creep. 


\begin{tabular}{|l|c|l|l|}
\hline Parameter & Symbol & Unit & Value \\
\hline $\begin{array}{l}\text { Marine sand transport } \\
\text { coefficient }\end{array}$ & $\mathrm{K}_{\text {sand }}$ & $\mathrm{m}^{2} / \mathrm{yr}$ & 500 \\
\hline Surface sand porosity & $\varphi_{\text {sand }}$ & - & 0 \\
\hline Sand e-folding depth & $\mathrm{z}_{\text {sand }}$ & $\mathrm{m}$ & 0 \\
\hline $\begin{array}{l}\text { Marine silt transport } \\
\text { coefficient }\end{array}$ & $\mathrm{K}_{\text {silt }}$ & $\mathrm{m}^{2} / \mathrm{yr}$ & 500 \\
\hline Surface silt porosity & $\varphi_{\text {silt }}$ & - & 0 \\
\hline Silt e-folding depth & $\mathrm{z}_{\text {silt }}$ & $\mathrm{m}$ & 0 \\
\hline Sand-shale ratio & $\mathrm{F}$ & - & 1 \\
\hline Thickness of transport layer & $\mathrm{L}$ & $\mathrm{m}$ & 100 \\
\hline Sea level & $\mathrm{h}_{\text {sea }}$ & $\mathrm{m}$ & 5000 \\
\hline
\end{tabular}

174 Table S2: FastScape model parameters.

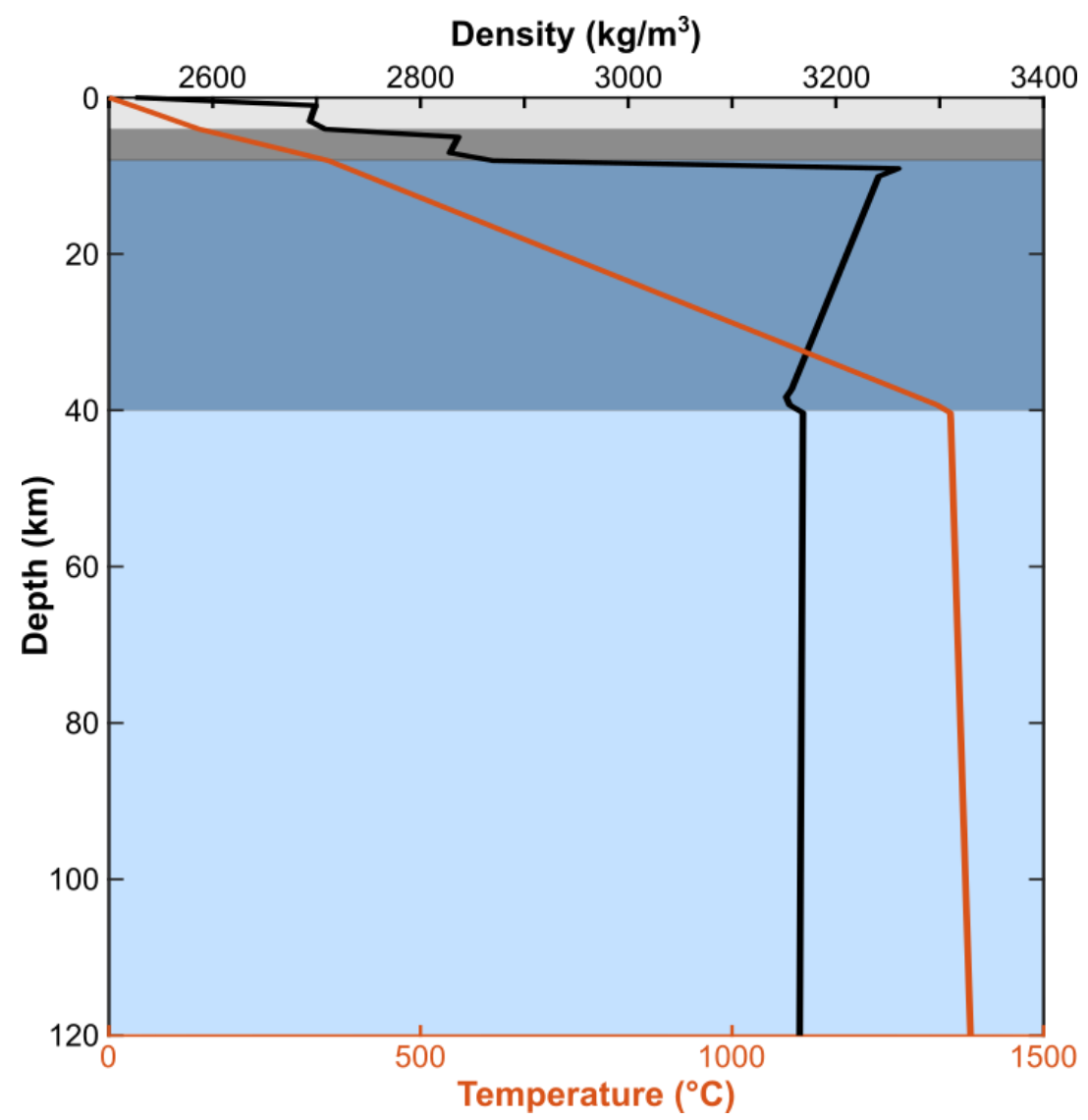

176 Figure S1: Initial density (black) and temperature (red) profiles with depth. Colored backgrounds

177 represent the initial compositions, with light gray representing the upper crust, dark gray the lower

178 crust, dark blue the mantle lithosphere, and light blue the asthenosphere. 


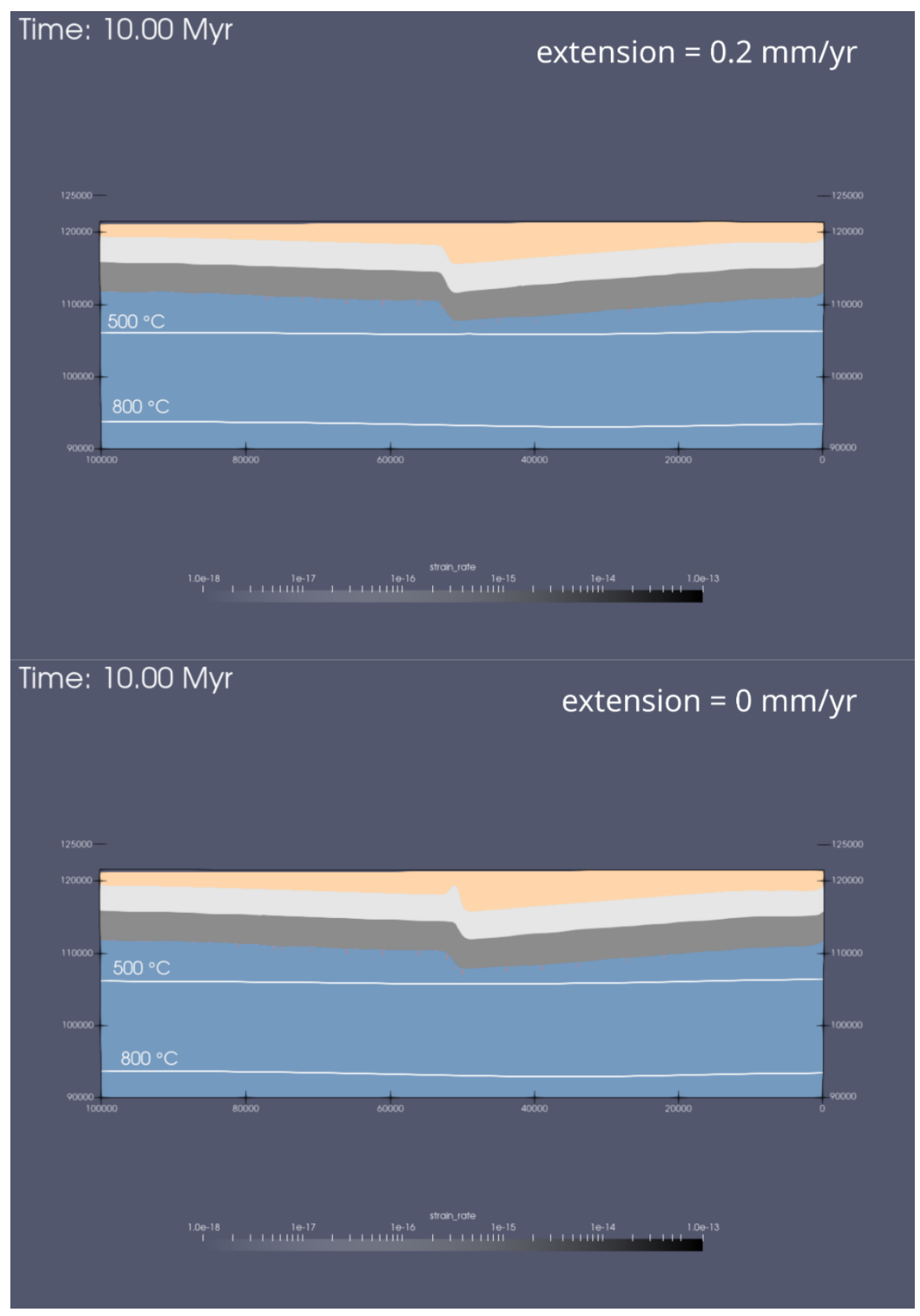

180 Figure S2: Comparison showing the reference model with A) a $0.2 \mathrm{~mm} / \mathrm{yr}$ extensional component.

181 B) no extensional component, leading to the formation of a small compressional pop-up in the 182 center. 


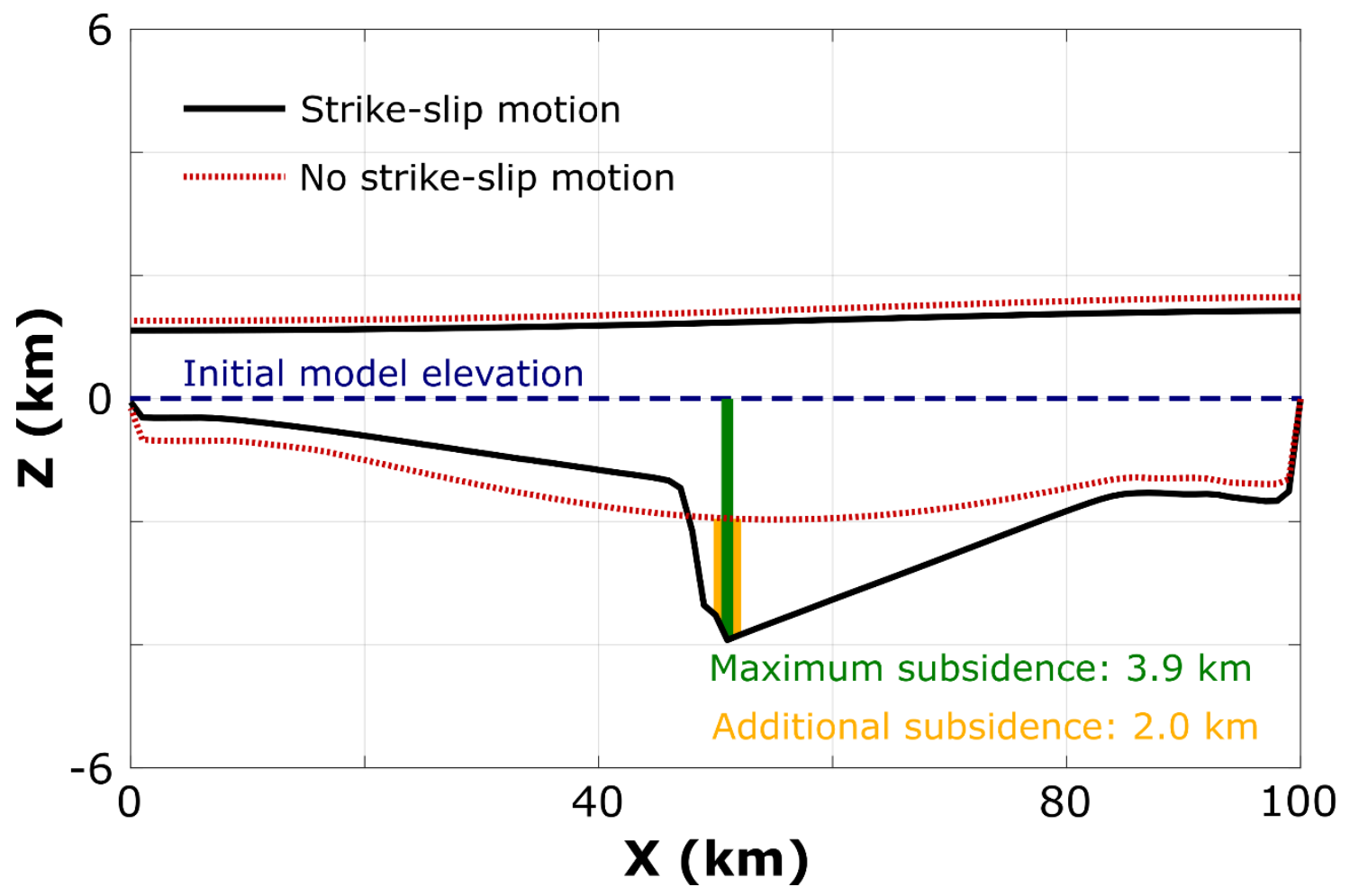

185 Figure S3: Comparison of the FastScape basement and topography from two models runs: The black curves represent the reference model; the dotted red curves show the reference model without

187 strike-slip motion. The dashed blue line represents the initial model elevation, the green line 188 indicates the total subsidence in the reference model with strike-slip motion, and the yellow line 189 shows the difference in subsidence when comparing models with and without strike-slip motion. 190 In the case without strike-slip motion, maximum subsidence and basin asymmetry are both greatly 191 reduced. 


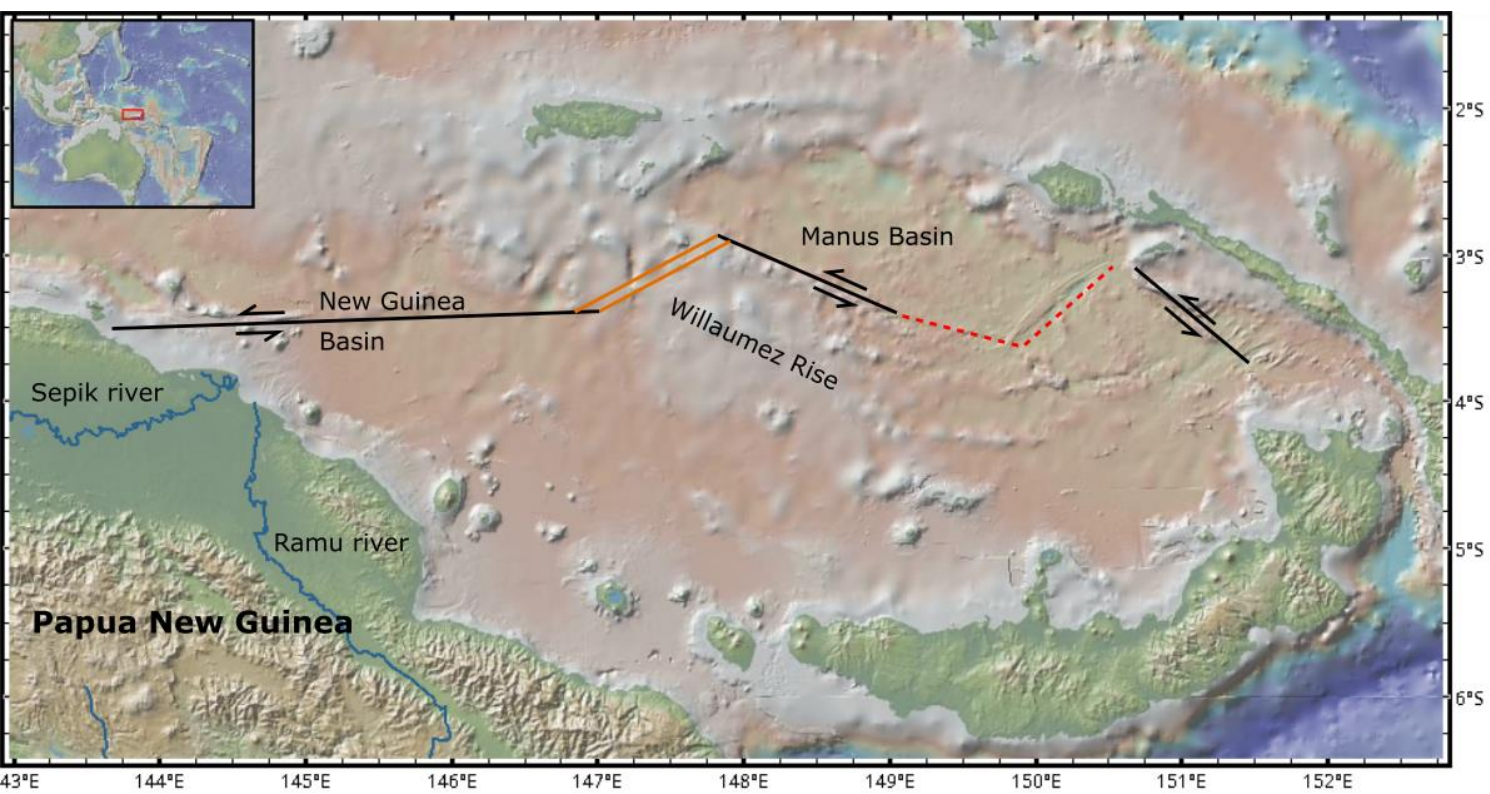

194 Figure S4: Regional map of the Manus back-arc region, with fault locations based on Fig. 1 in 195 Martinez and Taylor, 1996. Black lines indicate strike-slip faults, parallel orange lines spreading 196 centers, dashed red lines lava fields, and blue lines major rivers. This figure was made using 197 GeoMappApp (www.geomapapp.org; Ryan et al., 2009). 


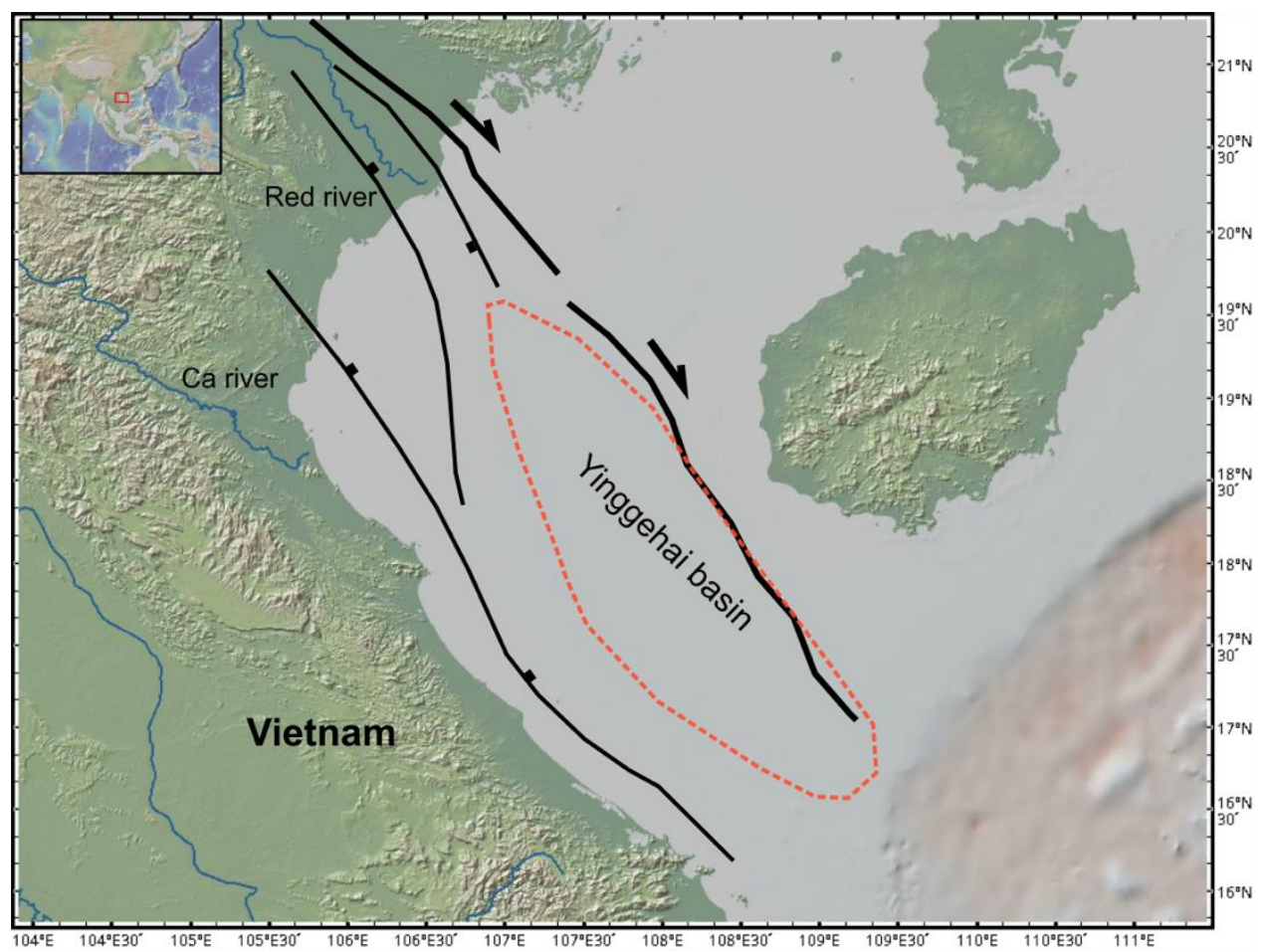

200

Figure S5: Regional map showing the Red River Fault Zone and location of the Yinggehai basin.

202 Fault locations based on Fig. 10 in Noda, 2013. Black lines show faults, blue lines major rivers,

203 and the Yinggehai basin is outlined in the dashed orange circle. This figure was made using

204 GeoMappApp (www.geomapapp.org; Ryan et al., 2009).

205

206

207 


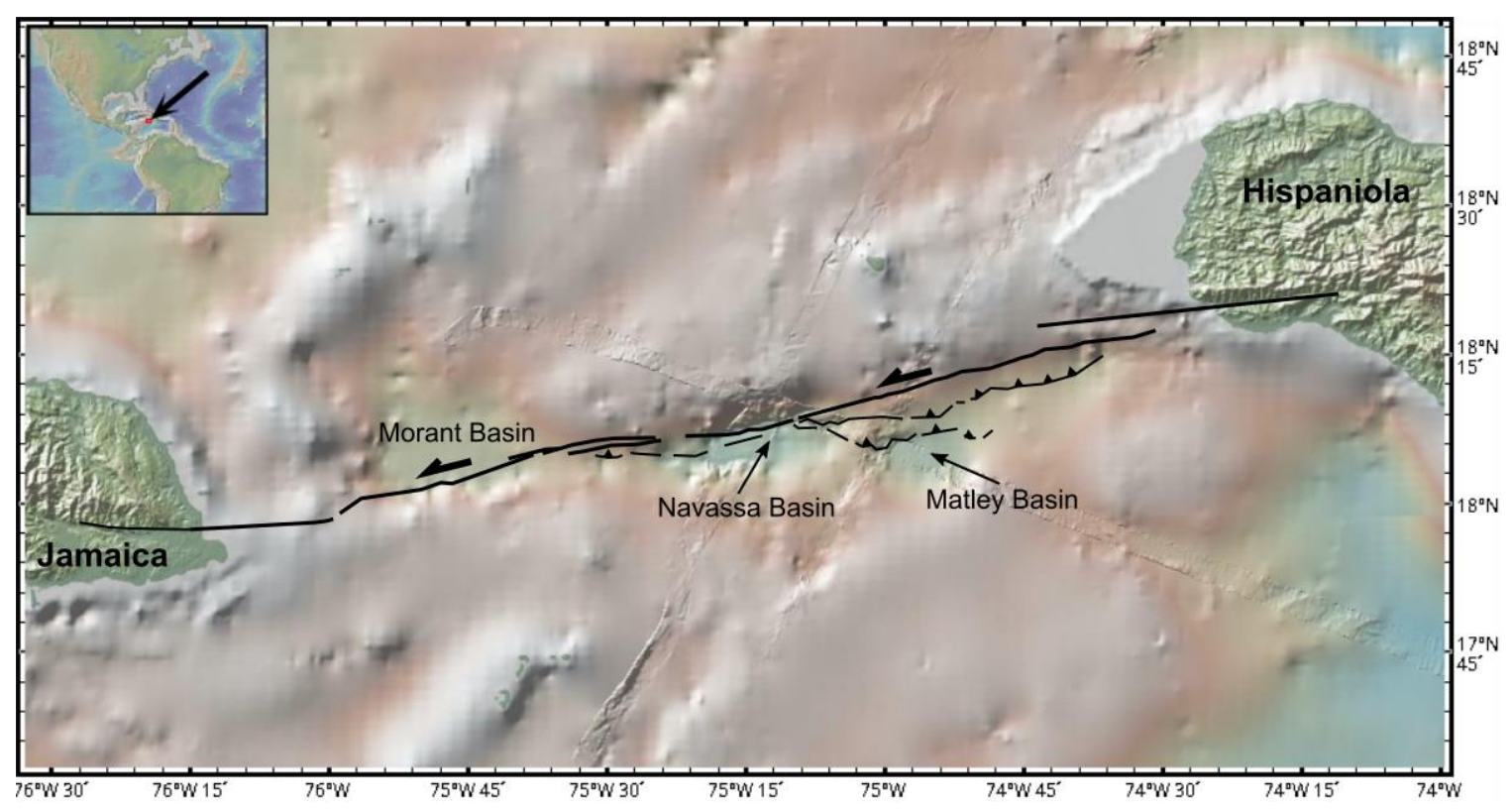

Figure S6: Regional map of the Jamaica Passage showing the Navassa strike-slip basin along the

210 Enriquillo-Plantain-Garden Fault Zone. Fault locations based on Fig. 6 in Corbeau et al., 2016.

211 This figure was made using GeoMappApp (www.geomapapp.org; Ryan et al., 2009).

213 Video S1: Full evolution of the tectonic reference model (Fig. 2C,K,G). Colors represent

214 composition where tan is sediment, light gray is upper crust, dark gray is lower crust, dark blue is

215 mantle lithosphere, and light blue is the asthenosphere. The white lines are temperature contours, 216 gray-scale the strain rate, and arrows indicate the total velocity magnitude.

218 Video S2: Evolution of the middle slice of the top $30 \mathrm{~km}$ of the reference tectonic model. Colors

219 represent composition where tan is sediment, light gray is upper crust, dark gray is lower crust, 220 dark blue is mantle lithosphere, and light blue is the asthenosphere. The white lines are temperature 
221

222

223

224

225

226

227

228

229

230

231

232

233

234

235

236

237

238

239

240

241

242

243

244

245

246

247

248

249

250

251

252

253

254

255

256

257

contours, gray-scale the strain rate, and red arrows indicate the subsidence rate ( $\mathrm{Z}$ velocity) along the $8 \mathrm{~km}$ depth contour.

\section{References}

Bangerth, W., Dannberg, J., Gassmoeller, R., and Heister, T., 2019, ASPECT v2.1.0: Zenodo, https://doi.org/10.5281/zenodo.2653531.

Braun, J., and Willett, S.D., 2013, A very efficient O(n), implicit and parallel method to solve the stream power equation governing fluvial incision and landscape evolution: Geomorphology, v. 180-181, p. 170-179, doi:10.1016/j.geomorph.2012.10.008.

Corbeau, J., Rolandone, F., Leroy, S., Mercier de Lépinay, B., Meyer, B., Ellouz-Zimmermann, N., and Momplaisir, R., 2016, The northern Caribbean plate boundary in the Jamaica Passage: Structure and seismic stratigraphy: Tectonophysics, v. 675, p. 209-226, doi:10.1016/j.tecto.2016.03.022.

Davis, R.O., and Selvadurai, A.P.., 2002, Plasticity and Geomechanics: Cambridge University Press.

Glerum, A., Thieulot, C., Fraters, M., Blom, C., and Spakman, W., 2018, Nonlinear viscoplasticity in ASPECT: Benchmarking and applications to subduction: Solid Earth, v. 9, p. 267-294, doi:10.5194/se-9-267-2018.

Heister, T., Dannberg, J., Gassmöller, R., and Bangerth, W., 2017, High Accuracy Mantle Convection Simulation through Modern Numerical Methods - II: Realistic Models and Problems.: Geophysical Journal International, v. 210, p. 833-851, doi:doi:10.1093/gji/ggx195.

Hirth, G., and Kohlstedt, D., 2003, Rheology of the upper mantle and the mantle wedge: a view from the experimentalists: Inside the Subudction Factory Geophysical Monograph (American Geophysical Union), v. 183.

Karato, S., and Wu, P., 1993, Rheology the Upper Mantle : Synthesis: v. 260.

Kronbichler, M., Heister, T., and Bangerth, W., 2012, High Accuracy Mantle Convection Simulation through Modern Numerical Methods.: Geophysical Journal International, v. 191, doi:doi:10.1111/j.1365-246x.2012.05609.x.

Mahattanachai, T., Morley, C.K., Charusiri, P., and Kanjanapayont, P., 2021, The Andaman Basin Central Fault Zone, Andaman Sea: Characteristics of a major deepwater strike-slip fault system in a polyphase rift: Marine and Petroleum Geology, p. 104997, doi:10.1016/j.marpetgeo.2021.104997.

Martinez, F., and Taylor, B., 1996, Backarc spreading, rifting, and microplate rotation, between transform faults in the Manus Basin: Marine Geophysical Researches, v. 18, p. 203-224, doi:10.1007/BF00286078.

Noda, A., 2013, Strike-Slip Basin - Its Configuration and Sedimentary Facies: Mechanism of 
Sedimentary Basin Formation - Multidisciplinary Approach on Active Plate Margins, doi:10.5772/56593.

Rose, I., Buffett, B., and Heister, T., 2017, Stability and Accuracy of Free Surface Time Integration in Viscous Flows.: Physics of the Earth and Planetary Interiors, v. 262, p. 90100, doi:doi:10.1016/j.pepi.2016.11.007.

Rouby, D., Braun, J., Robin, C., Dauteuil, O., and Deschamps, F., 2013, Long-term stratigraphic evolution of Atlantic-type passive margins: A numerical approach of interactions between surface processes, flexural isostasy and 3D thermal subsidence: Tectonophysics, v. 604, p. 83-103, doi:10.1016/j.tecto.2013.02.003.

Rutter, E.H., and Brodie, K.H., 2004, Experimental grain size-sensitive flow of hot-pressed Brazilian quartz aggregates: Journal of Structural Geology, v. 26, p. 2011-2023, doi:10.1016/j.jsg.2004.04.006.

Ryan, W.B.F. et al., 2009, Global Multi-Resolution Topography synthesis: Geochemistry, Geophysics, Geosystems, v. 10, doi:https://doi.org/10.1029/2008GC002332.

Rybacki, E., Gottschalk, M., Wirth, R., and Dresen, G., 2006, Influence of water fugacity and activation volume on the flow properties of fine-grained anorthite aggregates: Journal of Geophysical Research: Solid Earth, v. 111, doi:10.1029/2005JB003663.

Sippel, J., Meeßen, C., Cacace, M., Mechie, J., Fishwick, S., Heine, C., Scheck-Wenderoth, M., and Strecker, M., 2017, The Kenya rift revisited: Insights into lithospheric strength through data-driven 3-D gravity and thermal modelling: Solid Earth, v. 8, p. 45-81, doi:10.5194/se8-45-2017.

Turcotte, D.L., and Schubert, G., 2013, Geodynamics: Cambridge University Press.

Yuan, X.P., Braun, J., Guerit, L., Rouby, D., and Cordonnier, G., 2019a, A New Efficient Method to Solve the Stream Power Law Model Taking Into Account Sediment Deposition: Journal of Geophysical Research: Earth Surface, v. 124, p. 1346-1365, doi:10.1029/2018JF004867.

Yuan, X.P., Braun, J., Guerit, L., Simon, B., Bovy, B., Rouby, D., Robin, C., and Jiao, R., 2019b, Linking continental erosion to marine sediment transport and deposition: A new implicit and $\mathrm{O}(\mathrm{N})$ method for inverse analysis: Earth and Planetary Science Letters, v. 524, p. 115728, doi:10.1016/j.epsl.2019.115728. 